\title{
THE CHINA SYNDROME: THE IMPACT OF CHINA'S GROWING ECONOMIC AND POLITICAL INFLUENCE IN THE SOUTH PACIFIC
}

\section{Ige Kehinde Moses}

Department of Public Administration, Faculty of Political Science, and Economics, East Stroudsburg University, 200 Prospect St, East Stroudsburg, PA 18301, United States

Email: amazingkheni@gmail.com; Tel: +2349053073214, +1 (708) 745 -1164

\section{Cite this article:}

Ige Kehinde Moses (2021), The China Syndrome: The Impact of China's Growing Economic and Political Influence in the South Pacific. African Journal of Social Sciences and Humanities Research 4(3), 81-89. DOI: 10.52589/AJSSHRR3RFH1VU.

\section{Manuscript History}

Received: 31 May 2021

Accepted: 25 June 2021

Published: 6 July 2021

\section{Copyright $(92020$ The Author(s).} This is an Open Access article distributed under the terms of Creative Commons AttributionNonCommercial-NoDerivatives 4.0 International (CC BY-NC-ND 4.0 ), which permits anyone to share, use, reproduce and redistribute in any medium, provided the original author and source are credited.
ABSTRACT: The People's Republic of China in the past decades has experienced dynamic and accelerative growth. Its activities the world over, particularly in the South Pacific is a projection of its foreign policy as well as its economic and political ambition. While its growing power remains progressive, the dominant explanation for this trend is its desire to attain the hegemonic status that is unrivalled.

KEYWORDS: China, South Pacific, Influence, Impact. 


\section{INTRODUCTION}

\section{Preamble}

The People's Republic of China was established on the 1st of October, 1949, and served as a replacement to the Republic of China's government which was a sovereign state based in Mainland China before the relocation of its government to Taiwan. The birth of the PRC ushered in such modern and dynamic political and economic perspectives. These said perspectives shaped the ideals, orientation, national interest, foreign policy, and diplomatic relations of the People's Republic of China.

In an attempt to examine China's policy and polity of territorial and economic expansion, it is imperative to investigate and scrutinize China's approach in achieving its desired goals on a global scale within the confines of international law to the South Pacific as a case study.

"Although quickly embraced by a select group of Pacific Islanders, the modern idea of the South Pacific was to adapt Oscar Spate's phrase for the wider pacific, a European artefact meeting as the South Seas conference in a Canberra Grammar School in 1947, representatives of six colonial powers United States, Britain, the Netherlands, France, Australia, and New Zealand - created a formal region with etched-in boundaries to replace the hazier notions of the "South Seas" or "The Islands. After some debate over its naming, they decided to call it "The South Pacific", and established a regional institution, the South Pacific Commission (SPC), to promote "native welfare" in their pacific colonies" [Fry: 1997].

Sequel to the establishment of the South Pacific Commission in 1947, representatives of the colonial power held administrative control of the Commission's activities and as its outline and mandate were limited to development matters [Peebles: 2005].

The coastal states of the South Pacific are made up of Australia, Cook Islands, Fiji, Kiribati, Marshall Islands, Micronesia, Nauru, New Zealand, Niue, Palau, Papua New Guinea, Samoa, Solomon Islands, Tonga, Tuvalu, and Vanuatu. With some of these nations endowed with natural resources, it is pivotal for each state in the South Pacific to re-evaluate its position internationally concerning their national interests both as independent states and as a region.

This influences the foreign policy of each state as regards its diplomatic relations with any would-be power be it communist China or democratic Australia and the United Stated States. Every state has the power to determine and define the trajectory of its foreign relations.

The idea to turn the Islands into the Pacific was the economic and strategic value it brought in terms of shipping. Ocean-shipping companies, traders, and subsequently governments began to see them as junctions of Inter-Pacific sea routes. Fiji was particularly strategic because its location was referred to as the highway of commerce between Australia and Panama [Van Dijk 2015].

The South Pacific happens to be the last major region of the world to experience decolonization. In an attempt to take control of their destinies many Pacific communities paid particular attention to lessons learned from previous international experiences [Crossley: 1993]. The most prolific and influential powers have traditionally been Australia, the United States, New Zealand, and France. These nations worked together, collaborators particularly in regards to the 1992 France, Australia, and New Zealand agreement [FRANZ] - to promote cooperation in 
response to natural disasters such as accidents, earthquakes, and force majeure as well and to facilitate defence cooperation.

The Quadrilateral Defence Coordination Group established in 1998 by the same states sought to coordinate and oversee air and maritime surveillance. These four countries were also participants of multilateral activities such as the annual pacific partnership, humanitarian mission, and the biennial Rim of the pacific naval exercises, both led by the United States [Wallis: 2017].

Although the U.S. crucially marked down its presence in the South Pacific sequel to the Cold War, its interest intensified during Hilary Clinton's tenure as Secretary of State. Most significantly, Secretary of State Clinton's presence at the Pacific Islands Forum in Rarotonga in 2012 was an avenue whereby Clinton plainly staked the US place in the region, claiming that "we too, of course, are a Pacific nation". Although she laid little emphasis on US competition with China in the region, she cited Chinese endeavours to supplant Exxon Mobil as the primary stakeholder in a Liquefied Natural Gas project in PNG for example China happens to be present daily and in every way possible, trying to find out how it can come in behind us, come in under us [Walls: 2017].

As regards the United State policy in the South Pacific, it is evident that during the postwar era, the wide area of the South Pacific has been disregarded by successive U.S administrations as an attitude of "benign neglect". The strict adherence to policy benign neglect was understandable as a result of the US security objective, which was to ensure the security of both sea and aerial communications from North America to Southeast Asia and the Indian Ocean. [Young: 1988].

\section{CHINA'S FOREIGN POLICY}

The Summary of China's foreign policy entails the strategic relations with neighbouring countries and the world's superpowers to strive for China's national interest, thereby creating a conducive environment for China's development domestically and for its continual competition globally.

Foreign policy is the most important aspect of government because it has the potential to affect the largest number of people especially if it includes environmental policy. Foreign policy also includes some elements of economic policy. Foreign policy is a collection of policies that determine a country's relations with other nations. It is made up of various entities such as diplomacy, military, and security policy, international human rights, economic policies, and environmental policy. Foreign policy is the quintessential public good in the sense that everybody benefits from policies that make citizens of the world safer. Historians, officials, and theorists of international relations and diplomacy distinguish foreign policy behaviour by terms that propose patterned recurring choices and actions by the government, geared towards an outcome [Holski 1970].

Foreign policy goals include providing security, creating prosperity working towards the somewhat idealistic goal of making the world a better place. The concept of security for example has many facets. It used to simply mean being able to repel invaders. In addition to physical security, foreign policy encompasses transportation, cybersecurity, and food security. 
There are four processes in making foreign policy which is articulation, formulation, implementation, and evaluation. While there exist the possibility and tendencies that China poses threat to the western world, there is no meeting point as regards the nature of challenge it poses and this perception is derivative of China's history, traditions and from the Communist ideology of its present rulers while there have been certain tactical shifts in China since 1949, Chinese foreign policy under Communism has been relatively realistic and restrained. There is however the determination to reassert China as a world power considering China's size, population, and ever-growing strength [Taylor: 1966].

\section{DOMINION AND EXPANSIONISM}

The goals and objectives of China are rooted in expansion, control, and stability. Historically, China has been a major empire throughout its history. From its dynasties into its emergence as a full state. China's development could be traced back to the Northern basin of Huaxia which is said to be the Modem day yellow and Yangtze rivers. Medieval Chinese expansion could be traced back to the Mongols who founded the Yuan and Ming dynasties. The Yuan dynasty was particularly characterized by Sino Mongol expansionism as Yuan China facilitated attempts to conquer other territories [Robinson: 2008].

Modern Chinese expansion is credited to the Chinese Economic Reform of 1978. The Chinese Economic Reform otherwise known as Reform and Opening Up was the initiative termed as socialism and the socialist market economy in the People's Republic of China led by then Paramount ruler Deng Xiaoping. This was a series of reforms Launched by Reformists within the Chinese Communist Party. The 1978 Reformist leaders were aware of China's Military vulnerability, an economically frail and technologically undeveloped society. Sharing the longest border, they bore the consciousness of its transition to an economically successful, technologically advanced, and politically expansionist authoritarian state [Garnaut: 2018].

The escalation of the Sino-Soviet dispute and China's "four modernizations" provided the conditions for diplomatic reconciliation with the United States and Deng Xiaoping's Interim rehabilitation as Vice Premier in the early 1970s.

The scale and momentum of China's trade growth inevitably place duress on the economic structure in other countries [Garnaut: 2018].

China's political and economic policy has strategically positioned the nation in a manner that it has accumulated a lot of strength politically, economically, and militarily with a certain amount of anxiety or apprehension as regards the real intentions of China especially in regards to territorial expansion. A peculiar attribute to Chinese foreign policy is the use of strategy in terms of philosophy. This philosophical outlook grants China the opportunity to plan in the long term. China's expanding tentacles of influence could be traced to its desire to be the most powerful nation in the world.

China's approach in the South Pacific is that they put heavy investments into countries that simply don't have the means to pay back the debt and when these countries can't seem to pay what they owe, the Chinese will then take a port, or a territory or take an Island. If China can get a country so deep in debt that it can't pay back, then China will take something else in return. In Vanuatu for instance, and more specifically, the key strategic outpost of Luganville. 
During World War II, Luganville was America's second-largest base in the Pacific. Presently, China has built an immense wharf. It claims it's to help the Vanuatu government attract crew ships into the region. Some scholars and analysts perceive that the construction of the wharf project in Luganville is merely a mirage by the Chinese to establish itself in Vanuatu considering Vanuatu's limited tourist market. The general perception is that the rationale behind Chinese actions in Vanuatu is commercial influence, political influence, and ultimately military presence [Herr: 2019].

China has been able to establish and facilitate its expansionist ideology through the "debt trap". This malign intent or misunderstood generosity allows the Chinese government to hold sway over the small nations in the Pacific Islands [Herr 2019].

China's endeavours are not only peculiar to the South Pacific region. China has form when it comes to deathtrap diplomacy. The African nation of Djibouti as of the year 2019-2020 owed China a staggering 1.2 billion dollars and China has used part of that debt to create a fullyfledged naval base there. With few other natural arrests in Djibouti besides its location and twenty-three per cent of its populace living in poverty, Djibouti resulted in renting land to foreign armies of various nationalities and flags to generate revenue. Hence, China saw the establishment of its first overseas base in Djibouti in 2017 [Shen: 2019].

Port Vila which is the harbourside and main hub of Vanuatu is littered with Chinese-built landmarks. The China aid Vanuatu Pacific mini games stadium project was built for a regional game in 2017 but since the Vanuatu 2017 Pacific mini-games, it hasn't been used for much since then. For Instance, the vinification of Fiji is evident in its activities within the nation. China has intensified its diplomatic investments in the past decade. The month of April 2006, marked the inauguration of the China-Pacific Economic Development and Cooperation Forum. Then Chinese Premier Wen Jiabao visited Fiji for this purpose. Xi Jinping became the first Chinese President to make a trip to Fiji in November 2014 and subsequently announced his intention to elevate China's friendly and cooperative relationship with the Pacific Island countries. Chinese aid to Pacific Island countries has significantly increased, totalling $\$ 1.45$ billion as of November 2013. With China's heightened diplomatic endeavours, its eight diplomatic partners in the region have asserted their support for the "One China" policy at Chinese request. The Pacific Island countries such as Vanuatu, Fiji, Papua New Guinea have also vocalized their support for China over the South China Sea dispute [Zhang: 2017].

Few would disagree that China has become a global power as it has enjoyed decades of output growth [Hale: 2004].

The Belt and Road Initiative is perceived as China's economic pursuit for global influence, and the public face of China's grand strategy. China has sought global power and influence under the guidance and direction of President Xi Jinping by implementing the imposing strategy to Marshal Chinese economic, diplomatic, military, and disinformation resources with an emphasis on geoeconomic influence. The Chinese approach of influence and interference in the South Pacific has become quite bold, shameless, and presumptuous. Establishing a pattern of behaviour contrary to China's stated foreign policy principle of "non-interference" [Connolly: 2020].

There is the perception of the South Pacific as rural, remote and developing, it has become the subject of great power interest and although the region is not formally part of the Belt and Road 
Initiative, it is easy to imagine its integration into the initiative [Oosterveld, Wilms, Kertysova, De Wijk, Roos, Bhattacharyya, Tranakieva: 2018].

The Solomon Islands foreign policy dilemma is believed to be a result of her switch from Taiwan to China. In September 2019, the Solomon Islands severed diplomatic relations with China (Taiwan) and acknowledged its recognition of the People's Republic of China (China). This was a sequel to a series of public discussions by the Solomon Islands government expressing the uncertain nature of its relationship with Taiwan which was established in 1983.

Due to the growth of China's global influence, Beijing has been able to induce a number of countries to abandon Taiwan. In 2017, Panama cut off relations with Taiwan, so did EL Salvador, the Dominica Republic, and Burkina Faso in 2018. In 2019 Kiribati followed suit with the Solomon Islands and switched association with Taiwan to China, leaving just fourteen nations including the Holy See and four Pacific Island countries (Palau, The Republic of the Marshall Islands, Tuvalu, and Nauru) that continue to have diplomatic relations with Taiwan [Agorau: 2021].

The year 2016 marked the height of the diplomatic clash between China and Taiwan. The relationship between China and Taiwan has thus deteriorated immensely. China resumed diplomatic relations with the Gambia, a former diplomatic partner of Taiwan, in March 2016. In December 2016, Sao Tome and Principe switched their alliance from Taiwan to China [Zhang 2017].

In regards to Australia's response to China in the Pacific, Australia has moved from a posture of alert to one of alarm as regards China's growing presence in the Pacific. As one security analyst expounds, Canberra is increasingly concerned about Beijing's interests and endeavours in the Pacific Islands including attempts to sway political elites, political parties, and targeted pursuit of transportation and infrastructure projects in locations across Melanesia [Varrall: 2021].

The image of the South Pacific as a territory is dominated by overlapping splurges of Western influence. Whilst the newly independent states of the region have continued to rely on economic and security links with nations such as Australia, New Zealand, the United States, and even Japan [Biddick: 1989].

The arrival of China in the region has altered the long-standing influence of western powers in the region. Samoa officially known as the Independent State of Samoa founded on 1 January 1962. Historically speaking, the Chinese have experienced some misfortunes in Samoa. There are many tombs of Chinese indentured labourers dotting Samoan Soil, perhaps the only meaningful icons of Chinese input to the development of Samoa during the first half of this century.

Few graves are marked, the identity of many cannot be established, some have inscriptions on their tombs. On one tombstone, the identity of this particular Chinese labourer could not be established as his name was etched in the brittle slab. The Chinese kept close to their native land but the development of new colonies elsewhere, the discovery of gold, the urge to replace the loss of agricultural labour, and the emancipation of slaves changed all that. They also found their way to the less lucrative but inviting islands of the Pacific such as Hawaii, Tahiti, New Caledonia, Fiji, Solomon Islands, Papua New Guinea, Ocean Island (or Banana) Nauru, and 
Samoa. Before the introduction of indentured labour into Samoa in 1903, only a handful of Chinese settlers had made Samoa their home [Liya Ana: 1997].

Contrary to popular beliefs about China's debt-trap diplomacy in the Pacific, some believe China's intentions are genuine. The argument is that China is not the only donor in the region, nor the most significant. In any given year, more than 60 donors invest US \$2 billion in aid to the Pacific, equal to around 7 per cent of the region's total Gross Domestic Product (GDP) [Pryke: 2020].

In an attempt to re-evaluate China's engagement in the Pacific Islands, Fangyin states that one pivotal reason for China's involvement and engagement in the Pacific is due to its addition to trade. Due to immense trading in the Pacific, the international community is concerned about China's investment in Pacific Island countries. From the period of 2016 - 2018, Huawei, a Chinese telecommunications giant, launched a national broadband transmission network project in PNG and an undersea optical cable project to connect the Solomon Islands to Australia [Fangyin: 2021].

\section{THE IMPACT OF CHINA'S ECONOMIC AND POLITICAL INFLUENCE IN THE SOUTH-PACIFIC}

The implications and ramifications of China's influence in the South Pacific are both economic and political. China's influence has reached well beyond its borders from expensive highways to military bases. What are China's true intentions in the Pacific, does it affect long-standing relations in the region, and most importantly, what are the impacts of China's economic and political influence in the region.

China's rapid penetration of the South Pacific has left the nations of this region highly indebted and highly dependent. Chinese endeavours threaten the very political and economic makeup of these states. Despite China's strategic accomplishments in this region, China is yet to prove its economic and political involvements entail win-win outcomes [Jain: 2018].

The Pacific is known for its spotless beaches, geographic and cultural diversity. With a cumulative population of well under 13 million people, the dilemma of small size and remoteness make traditional economic pathways in these countries somewhat difficult. By virtue of their geographical location, South Pacific nations are amongst the most susceptible to natural disasters. Chinese actions and deliberations have come to inform nationalists, academics, and foreign observers alike of the reality that China is using its leverage through diplomacy, debt trade, and elite capture to establish a military base in the South Pacific. Because of the severe vulnerability of these countries, China and Chinese enterprises, through elite capture, bribery, and corruption, are constantly undermining institutions of governance, the constitution of these states as well as indirect control of territories and public facilities.

China has rapidly built its influence in the South Pacific. Although the Covid-19 has created a more enabling environment for China to further entrench itself in the region, this further limits the ability of member states of the Pacific region who are mostly dependent on tourism and natural resources to ward off Chinese tendencies to influence and control both the political and economic systems of these states. China's rise to global dominance has been ensured through 
the implementation of Chinese coercion, threats of negative actions with the intention to force target states to change behaviour [Zhang: 2021].

These actions have changed America and the world's perspective of China dramatically.

Once considered a potential stakeholder, China is now perceived as America's principal strategic competitor [Chhabra, Doshi, Hass Kimball: 2021].

The impact of China's political and economic influence in the South Pacific region breeds extreme tendencies for absolute dependency on China as well as tendencies for the systemic and outright control of countries in the South Pacific region.

\section{REFERENCES}

Aqorau, T. (2021). Solomon Islands' Foreign Policy Dilemma and the Switch from Taiwan to China. In SMITH G. \& WESLEY-SMITH T. (Eds.), The China Alternative: Changing Regional Order in the Pacific Islands (pp. 319-348). Australia: ANU Press. doi:10.2307/j.ctv1h45mkn.14.

Biddick, T. (1989). Diplomatic Rivalry in the South Pacific: The PRC and Taiwan. Asian Survey, 29(8), 800-815. doi:10.2307/2644627.

CHHABRA, T., DOSHI, R., HASS, R., \& KIMBALL, E. (2021). Introduction. In CHHABRA T., DOSHI R., HASS R., \& KIMBALL E. (Eds.), Global China: Assessing China's Growing Role in the World (pp. 1-22). Washington, D.C.: Brookings Institution Press. Retrieved May 30, 2021, from http://www.jstor.org/stable/10.7864/j.ctv1gn3ss3.4.

Connolly, P. (2020). The Belt and Road come to Papua New Guinea: Chinese geoeconomics with Melanesian characteristics? Security Challenges, 16(4), 41-64. Retrieved May 25, 2021, from https://www.jstor.org/stable/26976257.

Crossley, M. (1993). Introduction: Comparative and International Studies and Education in the South Pacific. Comparative Education, 29(3), 227-232. Retrieved May 21, 2021, from http://www.jstor.org/stable/3099325.

Fangyin, Z. (2021). A Reevaluation of China's Engagement in the Pacific Islands. In SMITH G. \& WESLEY-SMITH T. (Eds.), The China Alternative: Changing Regional Order in the Pacific Islands (pp. 233-258). Australia: ANU Press. doi:10.2307/j.ctv1h45mkn.11.

Fry, G. (1997). The South Pacific 'Experiment': Reflections on the Origins of Regional Identity. The Journal of Pacific History, 32(2), 180-202. Retrieved May 21, 2021, from http://www.jstor.org/stable/25169335.

Garnaut, R. (2018). 40 years of Chinese economic reform and development and the challenge of 50. In Garnaut R., Song L., \& Fang C. (Eds.), China's 40 Years of Reform and Development: 1978-2018(pp. 29-52). Acton ACT, Australia: ANU Press. Retrieved May 24, 2021, from http://www.jstor.org/stable/j.ctv5cgbnk.10.

Hale, D. (2004). China's Growing Appetites. The National Interest, (76), 137-147. Retrieved May 25, 2021, from http://www.jstor.org/stable/42895968.

Herr, R. (2019). Chinese influence in the Pacific Islands: The yin and yang of soft power (pp. 21-30, Rep.). Australian Strategic Policy Institute. Retrieved May 25, 2021, from http://www.jstor.org/stable/resrep23109.9.

Holsti, K. (1970). National Role Conceptions in the Study of Foreign Policy. International Studies Quarterly, 14(3), 233-309. doi:10.2307/3013584. 
Ige. K.M. (2018). The Impact of Xenophobic attacks on Nigeria - South Africa Relation. International Journal of Advanced Academic Research (IJAAR), 4(6), 93-110.

Jain, R. (2018). China's Economic Expansion in South Asia: Strengths, Challenges and Opportunities. Indian Journal of Asian Affairs, 31(1/2), 21-36. Retrieved May 30, 2021, from https://www.jstor.org/stable/26608821.

Liua'Ana, B. (1997). Dragons in Little Paradise: Chinese (Mis-) Fortunes in Samoa, 19001950. The Journal of Pacific History, 32(1), 29-48. Retrieved May 29, 2021, from http://www.jstor.org/stable/25169313.

Oosterveld, W., Wilms, E., Kertysova, K., De Wijk, R., Rõõs, H., Bhattacharyya, K., . . . Tranakieva, K. (2018). The Belt and Road Initiative Looks East: Political Implications of China's Economic Forays in the Caribbean and the South Pacific (pp. 46-58, Rep.). Hague Centre for Strategic Studies. Retrieved May 25, 2021, from http://www.jstor.org/stable/resrep19581.7.

Peebles, D. (2005). The Pacific Islands Forum. In Pacific Regional Order (pp. 58-80). Canberra: ANU Press. Retrieved May 21, 2021, from http://www.jstor.org/stable/j.ctt2jbk4c.11.

Pryke, J. (2020). (Rep.). East-West Center. Retrieved May 29, 2021, from http://www.jstor.org/stable/resrep24984.

Robinson, D. (Ed.). (2008). Culture, Courtiers, and Competition: The Ming Court (13681644). Cambridge (Massachusetts); London: Harvard University Asia Center. doi:10.2307/j.ctt1tg5q12.

Shen, O. (2019). CHINA'S BASE IN DJIBOUTI: WHO'S GOT THE POWER? In Golley J., Jaivin L., Farrelly P., \& Strange S. (Eds.), Power(pp. 205-210). Acton ACT, Australia: ANU Press. Retrieved May 25, 2021, from http://www.jstor.org/stable/j.ctvfrxqkv.23.

Taylor, C. (1966). China's Foreign Policy. International Journal, 21(3), 311-322. doi:10.2307/40199575.

Van Dijk, K. (2015). Planters, Traders and Labour in the South Pacific. In Pacific Strife (pp. 43-62). Amsterdam: Amsterdam University Press. Retrieved May 21, 2021, from http://www.jstor.org/stable/j.ctt15nmjw8.6.

Varrall, M. (2021). Australia's Response to China in the Pacific: From Alert to Alarmed. In SMITH G. \& WESLEY-SMITH T. (Eds.), The China Alternative: Changing Regional Order in the Pacific Islands (pp. 107-142). Australia: ANU Press. doi:10.2307/j.ctv1h45mkn.7.

Wallis, J. (2017). Crowded and complex: The changing geopolitics of the South Pacific (pp. 9-13, Rep.). Australian Strategic Policy Institute. Retrieved May 22, 2021, from http://www.jstor.org/stable/resrep04250.6.

Young, T. (1988). U.S. Policy and the South and Southwest Pacific. Asian Survey, 28(7), 775-788. doi:10.2307/2644700.

Zhang, D. (2017). China's Diplomacy in the Pacific: Interests, Means and Implications. Security Challenges, 13(2), 32-53. Retrieved May 25, 2021, from https://www.jstor.org/stable/26457717.

ZHANG, K. (2021). Beijing's Nonmilitary Coercion-Tactics and Rationale. In CHHABRA T., DOSHI R., HASS R., \& KIMBALL E. (Eds.), Global China: Assessing China's Growing Role in the World (pp. 33-40). Washington, D.C.: Brookings Institution Press. Retrieved May 30, 2021, from http://www.jstor.org/stable/10.7864/j.ctv1gn3ss3.6. 